\title{
Volcanic Ash-Danger to Aircraft in the North Pacific
}

he world's busy air traffic
corridors pass over
hundreds of volcanoes ca-
pable of sudden, explosive
eruptions. In the United States
alone, aircraft carry many
thousands of passengers and
millions of dollars of cargo
over volcanoes each day.
Volcanic ash can be a serious
hazard to aviation even thou-
sands of miles from an erup-
tion. Airborne ash can dimin-
ish visibility, damage flight
control systems, and cause jet
engines to fail. USGS and
other scientists with the
Alaska Volcano Observatory
are playing a leading role in
the international effort to
reduce the risk posed to
aircraft by volcanic eruptions.

As the crew of KLM Flight 867 struggled to restart the plane's engines, "smoke" and a strong odor of sulfur filled the cockpit and cabin. For five long minutes the powerless 747 jetliner, bound for Anchorage, Alaska, with 231 terrified passengers aboard, fell in silence toward the rugged, snow-covered Talkeetna Mountains (7,000 to 11,000 feet high). All four engines had flamed out when the aircraft inadvertently entered a cloud of ash blown from erupting Redoubt Volcano, 150 miles away.

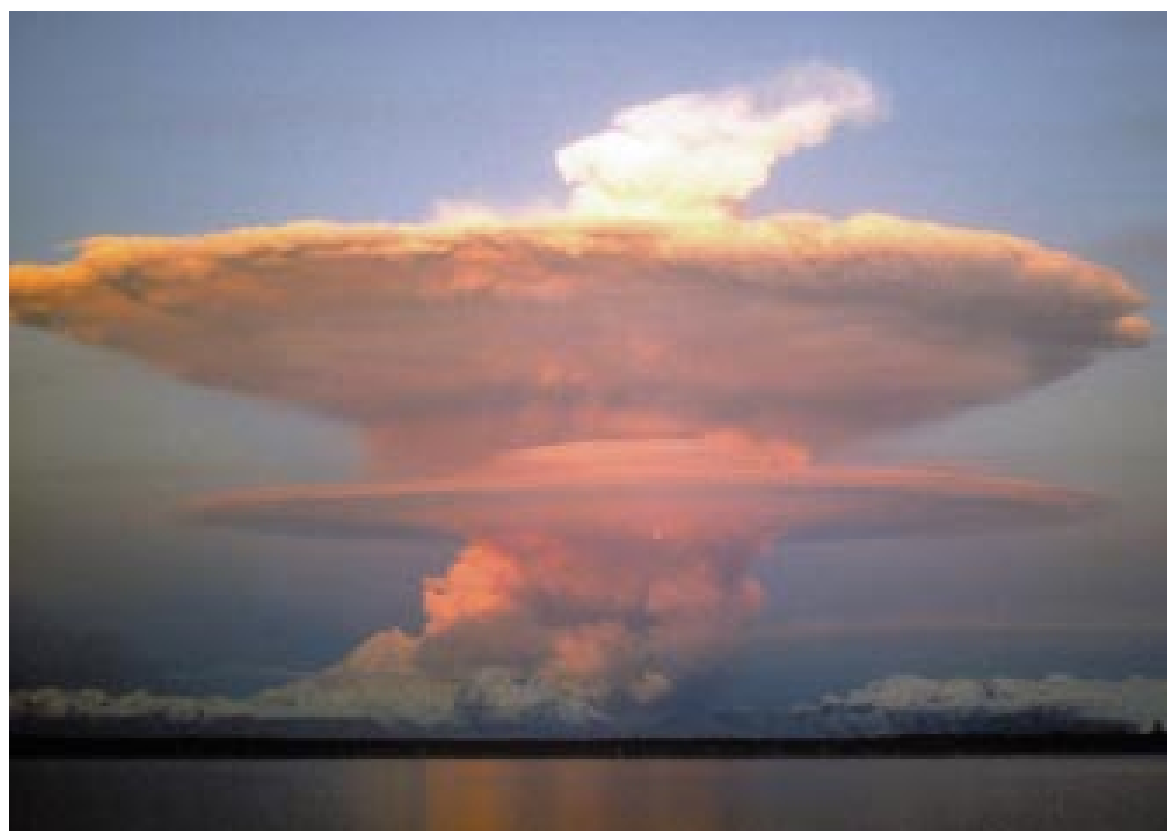

During a 1989-90 series of eruptions, Redoubt Volcano, Alaska, spewed enormous clouds of ash. Ash blown from this volcano on December 15, 1989, nearly caused a 747 jetliner (KLM Flight 867) carrying 231 passengers to crash. Partly in response to this near-fatal incident, the U.S. Geological Survey organized the first International Symposium on Volcanic Ash and Aviation Safety. This 1991 conference in Seattle, Washington, focused attention on ways to reduce the risk volcanic ash poses to the world's rapidly increasing air traffic. (Photo courtesy of Joyce M. Warren.)
The volcano had begun erupting 10 hours earlier on that morning of December 15, 1989. Only after the crippled jet had dropped from an altitude of 27,900 feet to 13,300 feet (a fall of more than 2 miles) was the crew able to restart all engines and land the plane safely at Anchorage. The plane required $\$ 80$ million in repairs, including the replacement of all four damaged engines.

Such dangerous and costly encounters between aircraft and volcanic ash can happen
Several times during the summer of 1992, ash clouds from explosive eruptions at Mount Spurr volcano, Alaska, significantly disrupted air traffic across the United States and Canada. In August, ash fall from one of these eruptions shut down Anchorage International Airport for 20 hours. The map (composite satellite image) shows the movement of the ash cloud from the September 16-17, 1992, eruption of

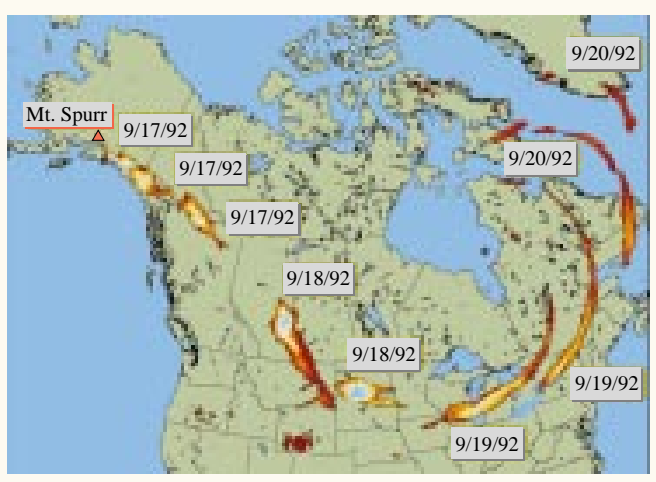
Mount Spurr. Photo shows an Alaska Volcano Observatory scientist installing a seismometer near Mount Spurr (in background). (Map by David Schneider, Michigan Technological University.)

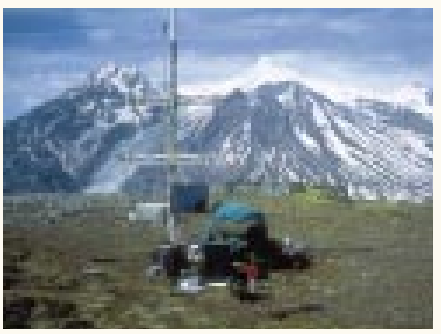

because ash clouds are difficult to distinguish from ordinary clouds, both visually and on radar. Also, ash clouds can drift great distances from their source. For example, in less than 3 days, the ash cloud from the June 15, 1991, eruption of Mount Pinatubo in the Philippines traveled more than 5,000 miles to the east coast of Africa. This ash cloud damaged more than 20 aircraft, most of which were flying more than 600 miles from the volcano.

Along North Pacific air routes, some of the busiest in the world, at least 15 aircraft (including KLM Flight 867) have been damaged since 1980 by flying through volcanic ash clouds. In the same period, there have been 80 such encounters worldwide, causing hundreds of millions of dollars in damage and lost revenue. Fortunately, no fatalities have yet occurred, but the growth in air traffic over volcanically active regions, such as the North Pacific, is increasing the chance of a deadly encounter.

More than 10,000 passengers and millions of dollars in cargo fly across the North Pacific region each day, and the area's aviation traffic is increasing about ten percent a year. This region also contains one of the most active parts of the "Ring of Fire," a belt of active volcanoes that borders much of the Pacific Ocean. About 100 potentially dangerous volcanoes lie under air routes in the North Pacific. Along 
the Alaska Peninsula and the Aleutian Islands there are more than 40 historically active volcanoes. Even greater numbers of active volcanoes are found to the west of Alaska on the Russian Kamchatka Peninsula and in the Kurile Islands.

Each year about 5 eruptions occur along the 2,400-nautical-mile arc from Alaska to the Kuriles. Ash clouds from volcanoes in this segment of the "Ring of Fire" are usually carried to the east and northeast, directly across busy air routes. On an average of 4 days a year in the North Pacific region, volcanic ash is present above an altitude of 30,000 feet, where most large jet aircraft fly.

In 1988, in part to address the hazard posed the U.S. Geological Survey (USGS), in cooperation with the University of Alaska Fairbanks Geophysical Institute and the Alaska Division of Geological and Geophysical Surveys, established the Alaska Volcano Observatory (AVO) with offices in Anchorage and Fairbanks. AVO provides hazard assessments, updates, and warnings of volcanic activity in ment agencies, airlines, and the public. AVO scientists also play a key role in monitoring eruptions and tracking ash clouds from volcanoes in the Russian Far East as part of a formal working relationship with the Russian Academy of Science's Kamchatkan Volcanic Eruptions Response Team (KVERT).

Accurate forecasts of volcanic eruptions are one way to help pilots avoid flying through ash clouds. To provide these essential early warnings, AVO operates networks of seismometers to detect earthquakes beneath volcanoes. Such quakes commonly mark the beginning of the unrest that can lead to eruptions. Recent supplemental funding from the Federal Aviation Administration (FAA) has made possible the tripling of the number of Alaskan volcanoes monitored by seismic networks. By late 1997, AVO expects to be operating such networks at 16 of the most dangerous volcanoes in Alaska.

AVO scientists also examine satellite data and work closely with the National Weather by airborne volcanic ash in the North Pacific, Alaska and is regularly consulted by govern-

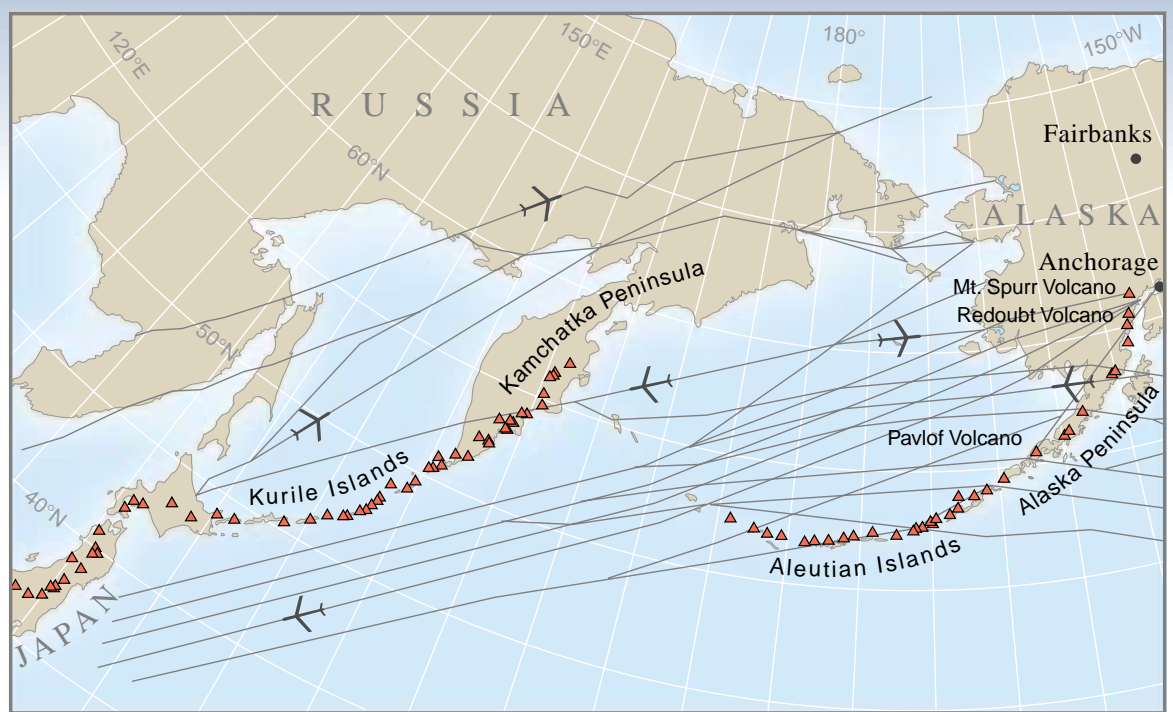

North Pacific and Russian Far East air routes (gray lines) pass over or near more than a hundred potentially active volcanoes (red triangles). Aircraft flying along these routes, some of the busiest in the world, carry more than 10,000 passengers and millions of dollars of cargo each day to and from Asia, North America, and Europe. In the North Pacific region, several explosive eruptions occur every year. Ash from these eruptions, which has caused jet engines to fail, is usually blown to the east and northeast, directly across the air routes.
Service to detect and track volcanic ash plumes in the North Pacific region. Other elements of the observatory's monitoring program include periodic observational overflights of the 40 potentially active Alaskan volcanoes. Some of these flights measure sulfur dioxide and carbon dioxide gas emissions from the volcanoes, as unusually high levels of these gases often precede volcanic eruptions. Because a volcano's past behavior provides important clues about possible future eruptions, AVO scientists are also conducting on-site geologic studies at Alaska's volcanoes, collecting data and samples for later analysis.

The monitoring techniques described above have enabled AVO to anticipate several Alaskan eruptions hours to weeks in advance, including events at Redoubt Volcano (1989) and Mount Spurr (1992). In September 1996, newly installed seismometers at Pavlof Volcano, on the Alaska Peninsula, quickly detected the onset of an eruption, enabling AVO to promptly alert the aviation community.

The successes of AVO are examples of the

\begin{tabular}{|l|l|l|}
\hline \multicolumn{4}{|c|}{ AVO LEVEL-OF-CONCERN COLOR CODE } \\
\hline \multicolumn{1}{|c|}{ Color } & \multicolumn{1}{|c|}{ Intensity of Unrest at Volcano } & \multicolumn{1}{c|}{ Forecast } \\
\hline GREEN & Volcano is in quiet, "dormant" state. & No eruption anticipated. \\
\hline YELLOW & $\begin{array}{l}\text { Small earthquakes detected locally and (or) } \\
\text { increased levels of volcanic gas emissions. }\end{array}$ & $\begin{array}{l}\text { An eruption is possible in the next few weeks and } \\
\text { may occur with little or no additional warning. }\end{array}$ \\
\hline ORANGE & $\begin{array}{l}\text { Increased numbers of local earthquakes. } \\
\text { Extrusion of a lava dome or lava flows (non- } \\
\text { explosive eruption) may be occurring. }\end{array}$ & $\begin{array}{l}\text { Explosive eruption is possible within a few days and } \\
\text { may occur with little or no warning. Ash plume(s) not } \\
\text { expected to reach 25,000 feet above sea level. }\end{array}$ \\
\hline RED & $\begin{array}{l}\text { Strong earthquake activity detected even at } \\
\text { distant monitoring stations. Explosive eruption } \\
\text { may be in progress. }\end{array}$ & $\begin{array}{l}\text { Major explosive eruption expected within 24 hours. } \\
\text { Large ash plume(s) expected to reach at least } 25,000 \\
\text { feet above sea level. }\end{array}$ \\
\hline
\end{tabular}

In 1989, the Alaska Volcano Observatory (AVO) developed a "color code" to rapidly and clearly communicate the likelihood of an eruption at potentially dangerous volcanoes. This format for summarizing the status of a volcano has proven extremely effective in alerting the aviation community to potential ash hazards in the North Pacific region. progress that can be achieved through cooperative efforts among various organizations. The observatory's work is making air travel safer by closely monitoring volcanoes in the North Pacific region and by rapidly alerting the aviation community to potentially dangerous ash clouds. In addition to active participation in AVO, the ongoing work of the USGS Volcano Hazards Program in the volcanically active regions of the United States, including Alaska, Hawaii, Arizona, California, and the Pacific Northwest, is helping to better protect people's lives and property from volcano hazards.

Christina A. Neal, Thomas J. Casadevall,

Thomas P. Miller, James W. Hendley II, and Peter H. Stauffer Graphic design by

Sara Boore and Susan Mayfield

COOPERATING ORGANIZATIONS

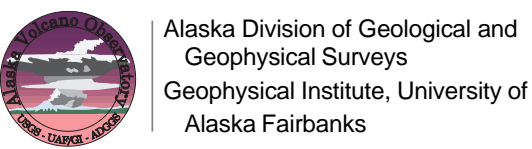

Federal Aviation Administration

Institute of Volcanic Geology and Geochemistry, Petropavlovsk, Kamchatka

Michigan Technological University

National Oceanic and Atmospheric Administration, National Weather Service

For more information contact:

Alaska Volcano Observatory (907) 786-7443

4200 University Drive

Anchorage, AK 99508

http://www.avo.alaska.edu/

See also What are Volcano Hazards? (USGS Fact Sheet 002-97)

U.S. Geological Survey Fact Sheet 030-97 1997 